\title{
Does Bacillus larvae produce an antibacterial substance in infected honey bee larvae?
}

\author{
Z Gliński 1, J Jarosz 2* \\ 1 University of Agriculture, Bee Diseases Research Laboratory, Akademicka 12; \\ ${ }^{2} \mathrm{M}$ Curie-Sklcodowska University, Department of Insect Pathology, \\ Akademicka 19, 20-032 Lublin, Poland
}

(Received 13 June 1991; accepted 20 November 1991)

\begin{abstract}
Summary - An effort was made to answer the question of whether production of antibacterial substance by Bacillus larvae, the cause of American foulbrood (AFB) disease, is the reason why bee larval cadavers (scales) contain a pure culture of that bacterium. Laboratory bioassays of antibacterial activity indicated the presence of an antibacterial agent in spent Bailey's culture medium used to grow $B$ larvae, whereas antibiotic activity was not detected in larval scales naturally infected with $B$ larvae. The antibacterial activity appears at the onset of $B$ larvae sporulation in artificial medium and its potency rises during sporulation of the pathogen. The agent has a broad spectrum of antibacterial activity against Gram-positive bacilli, micrococci and Gram-negative bacteria including Pseudomonas aeruginosa. The activity of the antibacterial substance was unaffected by proteolytic enzyme digestion and by pretreatment with proteolytically active, aqueous scale filtrates. Since the antibacterial compound is not liberated during infection, the presence of pure cultures of $B$ larvae found in bee cadavers cannot be explained simply by antibiosis. Because Apis mellifera larvae contain little or no indigenous microflora, pure cultures of $B$ larvae in cadavers from AFB infected brood could result from little or no competition for the infecting bacillus.
\end{abstract}

\section{American foulbrood / Bacillus larvae / antibacterial activity}

\section{INTRODUCTION}

When a host is killed by an insect pathogen, it may subsequently be attacked by secondary bacterial or fungal invaders (Burnside, 1930; Boyce and Fawcett, 1947; Dresner, 1949). Tissue residues of insects killed by ascomycete Cordyceps militaris are resistant to decay, apparently because of an antibiotic substance produced by the fungus (Cunningham et al, 1951). Similarly, Aspergillus species produce antibiotics that inhibit the overgrowth by saprophytes of dead insects, and beauveridicins produced by Beauveria bassiana ensure pure cultures of this fungus in the host cadavers (Hamil et al, 1969).

\footnotetext{
* Correspondence and reprints
} 
Holst (1945) stated that dried remains of honey bee (Apis mellifera L) larvae (scales) that had died from American foulbrood disease (AFB) almost invariably contain a pure culture of the causative agent Bacillus larvae, and therefore suggested that $B$ larvae might produce an antibiotic compound. Holst also observed inhibition zones around the scales on assay plates inoculated with a variety of indicator bacteria. Active preparations were obtained from scales held for over 4 years in the laboratory.

The question therefore arises of whether $B$ larvae produce an antibiotic-like substance in the infected honey bee brood. Our observations unequivocally confirm the presence of an antibacterial substance released into Bailey's liquid medium during sporulation of B larvae; however, the aqueous extracts of AFB scales were totally inactive.

\section{MATERIALS AND METHODS}

\section{Bacterial strains}

Two strains of $B$ larvae, $6 \mathrm{~S}$ and $2 \mathrm{~A}$, isolated on Bailey's solid medium (Bailey and Lee, 1962) from bee brood ( $A m$ mellifera $L$ ) that had died of American foulbrood disease were used to produce an antibacterial substance. About $0.1 \mathrm{~g}$ of dead brood was suspended in $2.0 \mathrm{ml}$ of sterile water and thoroughly blended using a glass tissue grinder. Ten $\mu$ l of fresh homogenate containing $B$ larvae endospores was streaked on Bailey's agar and incubated at $28^{\circ} \mathrm{C}$ for 1 week. Pure colonies of $B$ larvae were subsequently streaked onto Bailey's slants and maintained at $6{ }^{\circ} \mathrm{C}$.

Twelve bacterial species from several morphological groups (aerobic spore-forming bacilli, Gram-negative rods, micrococci, Corynebacterium) from laboratory collections were used as indicators to examine the spectra of antibacterial activity of the $B$ larvae strains.

\section{Release of antibiotic into liquid growth medium}

Each strain of $B$ larvae was grown in 5.0-ml vol of Bailey's liquid medium (Bailey and Lee, 1962) at $28^{\circ} \mathrm{C}$. The cultures left static were examined microscopically for spore formation and lysis of sporangia. To eliminate bacterial cells the cultures were cold-sterilized through a Schot G-5 funnel after $3,7,14$ and 21 days of incubation. Crude filtrates (spent media) obtained were examined for antibacterial activity.

\section{Larval scale extracts}

Aqueous larval scale extracts from a natural outbreak of AFB were examined for antibacterial activity. Fresh and 1-week-old AFB dead brood, hereafter called test samples I and $I$, and $\approx 1$ month-old AFB larval scales (test sample III) were each homogenized in distilled water. An aqueous mixture containing $3.0 \%(\mathrm{w} / \mathrm{v})$ of either the fresh dead brood, 1-week-old dead brood or larval scales was sterilized through G-5 funnel after removing the insect tissue using a sterile gauze. The samples prepared were examined by a cup diffusion agar assay technique. A total of 7 samples of AFB scales was examined for antibacterial activity against a wide range of bacterial indicators. Each sample consisted of a pool of dead brood collected from several combs with larvae from different colonies infected with B larvae. Part of the samples was maintained frozen for 2 years, then tested for antibacterial activity.

\section{Assay for antibacterial activity}

Each assay plate contained $10 \mathrm{ml}$ of soft $(0.7 \%)$ nutrient agar medium and $5 \mu \mathrm{l}$ of an indicator bacterium from an exponential phase of growth. The wells $(2.7 \mathrm{~mm}$ in diameter) were filled with $7.0 \mu \mathrm{l}$ of test sample: culture filtrate (spent Bailey's medium) or test sample I, II or III. After prediffusion of antibiotic at $4{ }^{\circ} \mathrm{C}$ for $3 \mathrm{~h}$, the assay plates were incubated at $28^{\circ} \mathrm{C}$ for $24-36 \mathrm{~h}$ to obtain a confluent lawn growth of the indicator bacteria. The diameter of growth inhibition zones produced around the wells indicated anti- 
bacterial activity of the sample and the sensitivity of the indicator bacteria.

\section{Effect of temperature on antibacterial activity}

A sample of spent Bailey's medium $(3.0 \mathrm{ml}$ of a cold-sterilized supernatant of 3-week-old $B$ larvae culture, strain $6 S$ ) was boiled in a water bath for 5, 10 and $15 \mathrm{~min}$. The antibacterial activity of boiled samples was tested by agar assay against the bacterial indicators Escherichia coli D31 and Pseudomonas aeruginosa (laboratory strain $\mathrm{H} 3$ ).

\section{Exposure of $\mathrm{B}$ larvae antibacterial compound to larval AFB scale extract and to proteolytic enzyme digestion}

An aliquot of $3.0 \mathrm{ml}$ of Bailey's medium filtrate (antibacterially active culture of $6 \mathrm{~S}$ strain) was mixed with an equal vol of $3.0 \%$ larval scale extract (sample III) and incubated at $24^{\circ} \mathrm{C}$ for 7 days. Another 2 samples of active filtrates (strain 6S, $3.0 \mathrm{ml}$ each) were treated with trypsin (Sigma Chemical Co) or Pronase P (from Streptomyces griseus; Calbiochem). Each proteolytic enzyme was added to the sample in equal volumes of Sörensen buffer $(0.066 \mathrm{M}, \mathrm{pH} 6.8)$ to a final concentration of $1.0 \mathrm{mg} / \mathrm{ml}$. Antibacterial activity was tested against $E$ coli and $P$ aeruginosa after 1,2 and 7 days of preincubation at $28^{\circ} \mathrm{C}$. Testing for antibacterial activity of spent Bailey's medium diluted $1 / 2$, aqueous larval scale extract, trypsin and Pronase $P$ served as controls.

\section{RESULTS}

Despite the suggestion of Holst (1945) that $B$ larvae produces an antibiotic-like substance in cadavers of dead honey bee larvae with symptoms of American foulbrood, our laboratory bioassays using test samples I, II and III detected no antibiotic activity, as shown in table I. Also shown is the antibacterial activity of spent Bailey's medium from cultures of $B$ larvae.

Even at a concentration of $3.0 \%$, an aqueous solution of sample I (fresh AFB larval filtrate) was inactive. Only slightly detectable activity against Bacillus subtilis and Sarcina lutea could be found for sample II (1-week-old AFB larvae) since sparse colonies of these indicators were grown around the wells only. The extracts prepared from sample III (1-month-old AFB scales) were inactive.

Artificial cultures of $B$ larvae grown on Bailey's liquid medium produced an antibacterial activity at the end of the stationary growth phase. Antibacterial potency increased with a prolongation of bacterial sporulation. For example, the bacterial strains multiplied heavily in the medium after 3 days of incubation at $28^{\circ} \mathrm{C}$, but filtrates prepared from these young cultures of $B$ larvae had no antibacterial activity. Bioassays of 7-day-old culture of $B$ larvae $6 S$, when the stationary growth phase ended, showed trace levels of antibiotic activity against $B$ subtilis, Sarcina lutea and Corynebacterium equi, but higher antibiotic activity against some other indicators. In general, an increase in the antibiotic potency coincided with sporulation of $B$ larvae in Bailey's medium (table I) and increased over time. $B$ subtilis, $S$ lutea and $C$ equi were moderately sensitive to $B$ larvae antibacterial substance from 7-day-old cultures, but were clearly inhibited by 14day-old cultures. This antibacterial activity still increased by day 21 in artificial medium of $B$ larvae cultures. Both strains of $B$ larvae showed activity against a similar range of indicator bacteria. Persistence of clear zones of growth inhibition of sensitive bacteria for at least 4 weeks pointed to biocidal rather than inhibitory action by the antibacterial substance.

Antibacterial activity was unaffected by boiling. Supernatant fluid of the $B$ larvae 


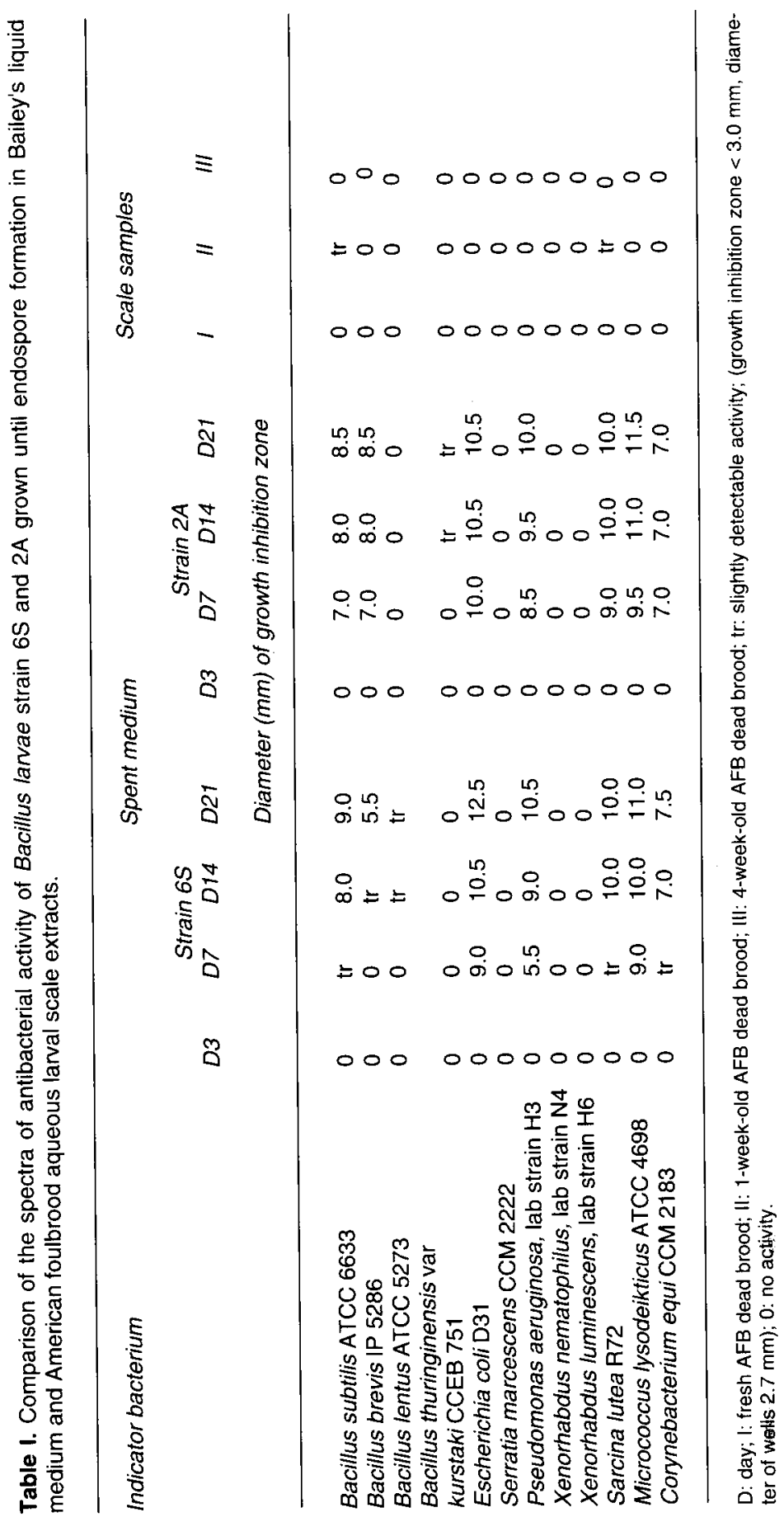


Table II. Heat stability of antibacterial compound of Bacillus larvae $6 \mathrm{~S}$ in spent Bailey's medium.

\begin{tabular}{lll} 
Sample & \multicolumn{2}{c}{ Growth inhibition zone $(\mathrm{mm})$} \\
& E coli D31 & P aeruginosa $\mathrm{H3}$ \\
\hline & & \\
Heated at $100^{\circ} \mathrm{C}$ for: & 10.5 & 9.0 \\
$5 \mathrm{~min}$ & 10.5 & 9.0 \\
$10 \mathrm{~min}$ & 10.5 & 8.5 \\
$15 \mathrm{~min}$ & 10.5 & 9.0 \\
Unheated & & \\
\hline
\end{tabular}

culture heated at $100^{\circ} \mathrm{C}$ for up to $15 \mathrm{~min}$ retained about the same level of activity against $E$ coli and $P$ aeruginosa as an unheated control sample (table II).

It appeared possible that if an antibiotic were present in the scales of bee larvae killed by AFB, it might have decomposed with time. To test this possibility, superna- tant fluids of $B$ larvae culture medium (strain 6S) were exposed to AFB scale extracts or to digestion by proteolytic enzymes. Then antibiotic activity was comppared with untreated samples of $B$ larvae supernatant culture fluid using a thin-layer soft agar inoculated with indicator bacteria. As shown in table III, trypsin or Pronase $\mathrm{P}$

Table III. Effect of proteolytic enzymes and American foulbrood larval scale extract on the potency of the antibacterial activity produced by Bacillus larvae in Bailey's medium*.

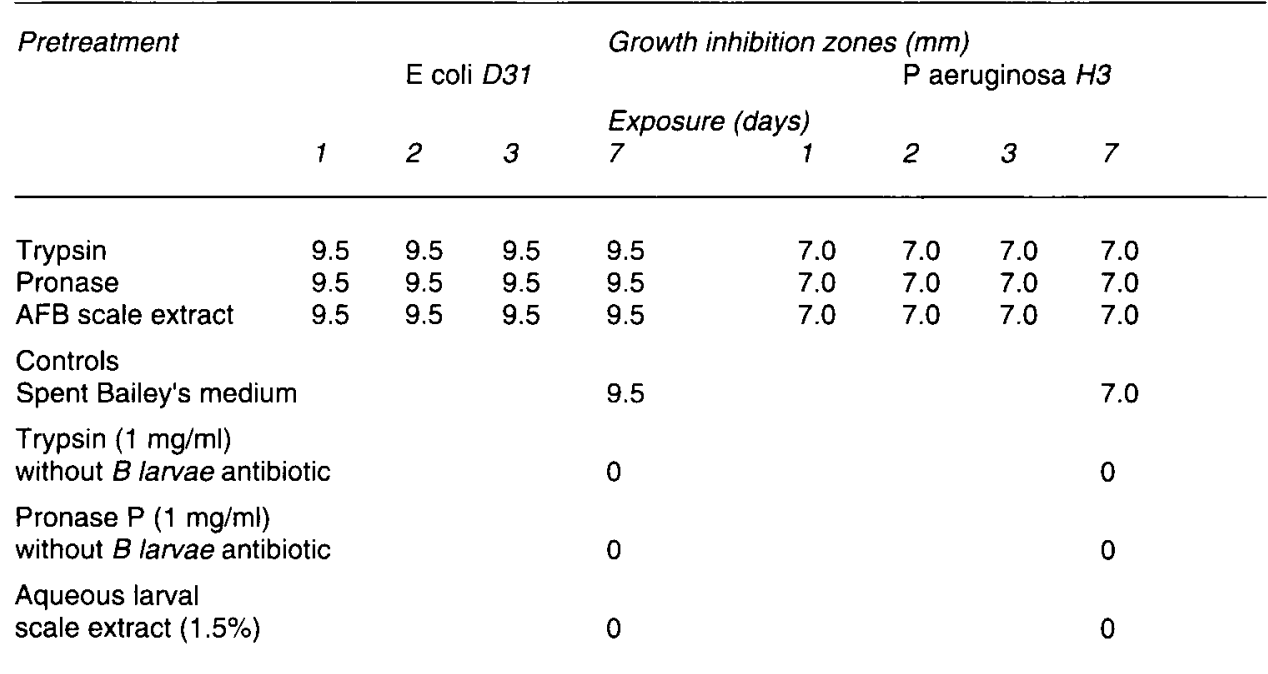

* Spent Bailey's medium of 21-day-old culture of $B$ larvae strain $6 S$ treated with trypsin, pronase $P$ and AFB scale extract was diluted $1 / 2$, similar to control spent Bailey's medium. 
at extremely high concentrations did not affect the potency even after 7 days and no decrease in activity was observed after 7 days of exposure to the scale extract. No decrease in antibacterial potency of frozen 2-year-old samples of bacterial supernatant was found.

\section{DISCUSSION}

Holst (1945) suggested that pure cultures of $B$ larvae found in cadavers of AFB diseased honey bee larvae resulted from production of an antibiotic substance by the pathogen. In view of the results presented herein, it is doubtful whether an antibiotic or antibiotic-like substance is produced in the larvae of Apis mellifera killed by AFB. Since the antibacterial compound in this investigation was released during sporulation of $B$ larvae on artificial medium but not during natural infecton (fig 1), the ex-

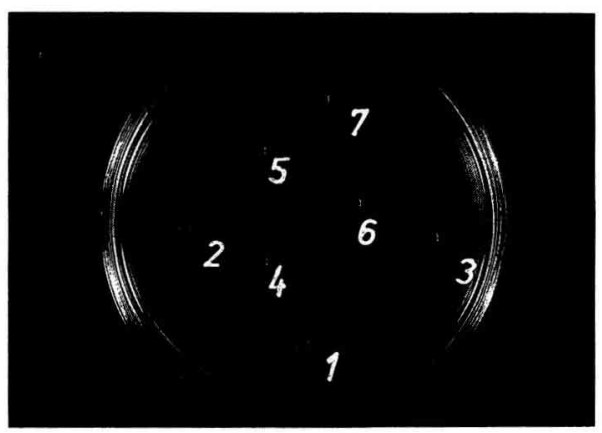

Fig 1. Growth inhibition zones of Escherichia coli D31 produced by an anti-bacterial substance released into Bailey's liquid medium by Bacillus larvae: 7-day old (1), 2-week old (2) and 3-week old (3) spent bacterial culture media and lack of inhibitory effects of fresh (4), 1-week (5) and 1-month-old (6) aqueous AFB larval scale extracts. No 7 is a 2-week old $B$ larvae spent medium boiled for $15 \mathrm{~min}$ and shows antibacterial activity. istence of pure cultures of $B$ larvae in bee cadavers cannot simply be explained by antibiosis. Nevertheless, antibacterial activity against a broad spectrum of bacteria was detected when $B$ larvae sporulated in Bailey's liquid medium. All test samples from natural infections examined for antibacterial activity were negative; antibacterial activity was not present in freshly dead brood and 1-month-old larval scales collected from natural outbreaks of the disease. Obviously, trace activity against $B$ subtilis and $S$ lutea found in test sample II (1-week-old AFB larvae) does not explain the observed pure cultures of $B$ larvae by antibiotic inhibition of contaminating bacterial flora. Since $B$ larvae is invariably isolated in pure cultures from scales some other mechanism must operate in the infected bee.

It is possible that pure cultures of $B$ larvae in scales result because bee larvae contain little or no indigenous microflora (Glinski and Jarosz, 1988) to compete with the pathogen. The experiments show that an antibacterial substance was not present in the scales of the dead larvae. Neither proteolytic enzymes at extremely high concentrations nor proteases present in scale extracts (Jarosz and Glinski, 1990) affected the antibacterial potency present in spent culture media (table III). The possibility also exists that $B$ larvae colonization of the honey bee brood creates unfavourable conditions for growth and multiplication of other organisms, thereby allowing the growth of the pathogen only in pure culture in infected larvae.

It is well known that some strains of microorganisms are antibiotic producers, whereas others are not. Therefore one can speculate that $B$ larvae examined by Holst (1945) was an antibiotic-producing strain. This could explain the antibiotic activity in the AFB scales examined. The antibiotic found by Holst (1945) in the water extract 
of AFB scales was a moderately heatstable substance with an activity which was markedly inhibited by the presence of glucose. In contrast, no detectable loss in activity of the antibacterial compound liberated in Bailey's medium was detected after boiling for $15 \mathrm{~min}$ (see table II). Moreover, in contrast to earlier findings, the activity was unaffected by glucose at a concentration of up to $2.0 \%$ added to the assay plates (Glinski and Jarosz, unpublished data). Thus, the antibacterial substance released by $B$ larvae growing artificially in Bailey's medium and the one described by Holst may differ. All the more as antibacterial activity produced in Bailey's medium by the strains of $B$ larvae examined in this investigation was easily detectable, even as traces, using the cup agar diffusion assay technique. But, as noted by Holst (1945), the cup assay method did not prove feasible for evaluation of antibiotic activity present in the AFB bee larval scales.

The antibacterial agent liberated by $B$ larvae during sporulation in Bailey's medium could be tentatively classified as belonging to a group of autolytic substances produced by spore-forming bacilli (Greenberg and Halvorson, 1955; Young, 1966) rather than to bactericides or antibiotics that are released during the exponential phase of bacterial growth. A specific autolytic substance is produced in sporulating cultures of $B$ subtilis (Nomura and Hosoda, 1956). On the other hand, $B$ subtilis autolysin is a thermolabile enzyme of a lytic activity directed against vegetative cells of $B$ subtilis but not against Escherichia coli and other Gram-negative bacteria. Under the above circumstances, it can be concluded from the experiments presented in this paper that $B$ larvae produces an antibacterial substance of a largely undetermined nature in artificial cultures but not in $A$ mellifera brood infected with this bee pathogen.
Résumé - Bacillus larvae produit-il une substance antibactérienne dans les larves d'abeilles infectées ? Holst (1945) a suggéré que les larves d'abeilles (Apis mellifera) mortes de la loque américaine (AFB) hébergeaient presque toujours une culture uniforme de Bacillus lanae. II expliquait les cultures pures de $B$ larvae trouvées dans les cadavres de larves d'abeilles (écailles loqueuses) par la production par l'agent pathogène d'une substance de type antibiotique. Nos recherches approfondies sur l'activité antibactérienne montrent la présence d'un agent antibactérien dans les cultures artificielles de $B$ larvae, mais pas dans les écailles des larves d'A mellifera infectées naturellement par $B$ larvae. En conséquen$c e$, les cultures pures de $B$ larvae trouvées dans les cadavres d'abeilles ne peuvent pas s'expliquer simplement par l'effet antibiotique; elles pourraient plutôt résulter d'une compétition nulle ou faible avec le bacille infectant, puisque la microflore est pratiquement inexistante chez les larves d'A mellifera.

L'activité antibactérienne contre une large gamme de bactéries Gram- et Gram+ apparaît au début de la sporulation de $B$ larvae dans le milieu de Bailey et sa force augmente au cours de la sporulation de l'agent pathogène (tableau I). Par contre, aucune activité antibactérienne n'a pu être mise en évidence dans les échantillons de couvain mort d'AFB et prélevés à diverses phases de décomposition (au moment de la mort, une semaine après, un mois après) (tableau I), quels que soient la colonie ou le rayon d'où ils provenaient. L'hypothèse selon laquelle une substance de type antibiotique présente dans les écailles loqueuses serait décomposée par des enzymes protéolytiques ou avec le temps, est à rejeter puisque, ni la trypsine, ni la pronase $\mathrm{P}$ à très fortes concentrations ne modifient l'activité antibactérienne des cul- 
tures sur milieu de Bailey, même après 7 jours d'exposition. De même, aucune diminution de l'activité n'a été notée lorsque les échantillons ont été exposés à des extraits d'écailles ayant une activité protéolytique (Jarosz et Glin'ski, 1990) (tableau III). On n'a noté en outre aucune diminution de l'action antibactérienne d'échantillons congelés pendant 2 ans dans le milieu de culture de Bailey.

L'activité antibactérienne observée par Holst (1945) dans les écailles loqueuses pourrait s'expliquer par le fait qu'il a étudié une souche de $B$ larvae capable de synthétiser dans les larves une substance antibiotique.

Apis mellifera / loque américaine / Bacillus larvae / activité antibactérienne

\section{Zusammenfassung - Produziert Bacil- lus larvae eine antibakterielle Substanz in der infizierten Bienenlarve? Holst} (1945) schloß aus seinen Versuchen, daß bei allen Bienenlarven (Apis mellifera), die an der amerikanischen Faulbrut (AFB) sterben, Bacillus larvae ausnahmslos in Reinkultur vorkommt. Die Reinkultur von $B$ larvae in toten Bienenlarven (im Schorf) erklärt er damit, daß der Bacillus eine den Antibiotika ähnliche Substanz erzeugt. Unsere umfangreichen Untersuchungen über antibakterielle Aktivität ergaben, daß zwar ein antibakterielles Agenz in künstlichen Kulturen (Bailey's Medium) vorhanden ist, aber nicht im Schorf der Larven bei natürlicher Infektion. Deshalb kann man die Reinkultur von $B$ larvae in toten Larven nicht einfach durch Antibiosis erklären; da $A$ mellifera Larven nur wenig oder gar keine natürliche Mikroflora haben, ist die Reinkultur wahrscheinlich auf wenig oder keine Konkurrenz durch andere Bakterien zurückzuführen.

Die antibakterielle Aktivität in Bailey's Medium gegen einen weiten Bereich von
Gram-negativen und Gram-positiven Bakterien erscheint bei dem Beginn der Sporulation von $B$ larvae, die Wirkung steigt während der weiteren Sporulation (Tabelle I) an. Dagegen konnte bei Proben von Brut, die durch AFB abgestorben war, auch bei verschiedenen Phasen der Zersetzung (frisch, nach 1 Woche, nach 1 Monat) keine antibakterielle Aktivität nachgewiesen werden. Das galt für alle Proben, die aus verschiedenen Völkern und von verschiedenen Waben gewonnen wurden.

Es ist unwahrscheinlich, daß zwar eine antibakterielle Substanz im Schorf der Larven vorhanden ist, diese Substanz aber durch proteolytische Enzyme abgebaut wird oder von geringer Haltbarkeit ist. Trypsin oder Pronase $P$ hatten trotz extrem hoher Konzentration und langer Einwirkung (7 Tage) keinen Effekt auf die antibakterielle Aktivität der Kulturen in Bailey's Medium. Es wurde ebenfalls keine Verminderung der Aktivität erreicht, wenn die Proben für 7 Tage den proteolytischaktiven Extrakten des Schorfs (Jarosz and Glinski, 1990) ausgesetzt waren (Tabelle III). Außerdem wurde keine Minderung der antibakteriellen Wirkung bei Proben beobachtet, die 2 Jahre in Bailey's Kulturmedium eingefroren waren.

Die antibakterielle Aktivität, die Holst (1945) bei seinen AFB Proben im Schorf fand, könnte damit erklärt werden, daß er einen anderen Stamm von $B$ larvae untersuchte, die die Fähigkeit hatte, antibiotische Substanzen in den Larven zu synthetisieren.

Apis mellifera / Bacillus larvae / amerikanische Faulbrut / antibakterielle Aktivität

\section{REFERENCES}

Bailey L, Lee DC (1962) Bacillus larvae: its cultivation in vitro and growth in vivo. $J$ Gen $\mathrm{Mi}$ crobiol 29, 711-715 
Boyce AM, Fawcett HS (1947) A parasitic Aspergillus on mealybugs. J Econ Entomol 40, 702-705

Burnside EC (1930) Fungous diseases of the honey bee. US Dept Agric Techn Bull 149, $43 \mathrm{pp}$

Cunnigham KG, Hutchinson SA, Manson W, Spring FS (1951) Cordycepin, a metabolic product from cultures of Cordyceps militaris (Linn) Link. Part I. Isolation and characterization. J Chem Soc 22, 99-122

Dresner E (1949) Culture and use of entomopathogenous fungi for the control of insect pests. Contrib Boyce Thompson Inst 15, 319-335

Glinski Z, Jarosz J (1988) Mikroflora pszczoly miodnej Apis mellifera. Postepy Mikrobiol 27, 95-108

Greenberg RA, Halvorson HO (1955) Studies on the autolytic substance produced by an aero- bic spore-forming bacterium. $J$ Bacteriol 69 , 45-50

Hamil RA, Higgens CE, Boar HE, Gorman M (1969) The structure of beauvericidin, a new depsipeptide antibiotic toxic to Artemia salina. Tetrahedron Lett 49, 4255

Holst EC (1945) An antibiotic from a bee pathogen. Science 102, 593-594

Jarosz J, Glinski Z (1990) Selective inhibition of cecropin-like activity of insect immune blood by protease from American foulbrood scales. $J$ Invertebr Pathol 56, 143-149

Nomura M, Hosoda J (1956) Nature of the primary action of the autolysin of Bacillus subtilis. J Bacteriol 72, 573-581

Young FE (1966) Autolytic enzyme associated with cell walls of Bacillus subtilis. J Biol Chem 241, 3462-3469 